Saudi Journal of Business and Management Studies Abbreviated Key Title: Saudi J Bus Manag Stud ISSN 2415-6663 (Print) |ISSN 2415-6671 (Online) Scholars Middle East Publishers, Dubai, United Arab Emirates Journal homepage: https://saudijournals.com/sjbms

\title{
The Implementation of Academic Supervision to Improving the Learning Quality in State Islamic Senior High School One and Two (Man 1 and Man 2) Trenggalek, East Java, Indonesia
}

\author{
Yumnan Abadi ${ }^{1}$, Maftukhin ${ }^{2}$, Imam Fuadi ${ }^{2}$, Akhyak ${ }^{2 *}$ \\ ${ }^{1}$ Doctor of State Islamic Institute of Tulungagung, East Java, Indonesia \\ ${ }^{2}$ Professor of State Islamic Institute of Tulungagung, East Java, Indonesia
}

\author{
DOI: $10.36348 / \mathrm{sjbms.2020.v05i02.005}$
}

| Received: 05.02.2020 | Accepted: 13.02.2020 | Published: 23.02.2020

*Corresponding author: Akhyak

\section{Abstract}

Academic supervision has a very important role in implementing an effective learning process as an effort to improve the quality of learning at school. The duty and responsibility of the principal as a supervisor is to improve the professionalism of the teacher in the process of learning activities. This study uses a qualitative approach while the data collection techniques are done through participant observation, in-depth interviews, and documentation studies. This research was conducted in MAN 1 Trenggalek and MAN 2 Trenggalek East Java, Indonesia. The results of this study indicate that the headmaster in implementing supervision of learning, adjusting to the plans outlined in the supervision program, using instruments and observation sheets, using the principles of supervision, using techniques and approaches that are varied and implemented with a pleasant atmosphere. The Islamic school head takes strategic steps as an embryo of success in implementing the supervision of learning in the school.

Keywords: Academic supervision, implementation, learning quality.

Copyright @ 2020: This is an open-access article distributed under the terms of the Creative Commons Attribution license which permits unrestricted use, distribution, and reproduction in any medium for non-commercial use (NonCommercial, or CC-BY-NC) provided the original author and source are credited.

\section{INTRODUCTION}

At present, the important role of education determines the quality of human resources. The quality of a nation and its state is not only marked by its natural beauty and wealth, but its main location lies in the excellence of human resources. The excellence of human resources is closely related to the quality of education. The quality of education is often marked by good condition and fulfills the requirements in all components of education which include the process, outputs, education staff, infrastructure, and costs. Meanwhile, the quality of education cannot be separated from the process of education and teaching that takes place at an educational institution, which institution demands a systematic and planned coordinating effort.

Ara Hidayat and Imam Machali [1] state that these efforts can be realized with the implementation of supervision. Supervision has an important role in efforts to improve the competence and professional abilities of teachers. Supervision is nothing but the application of several democratic principles so that human potential can develop continuously both in the context of personal and shared life, and everyone can participate in a community. Therefore, supervision or supervision is a very important part and cannot be separated to improve the quality of education, both those in schools or Islamic schools. Improving the quality of education is not an easy task due to it is influenced by various factors, such as the quality of educational inputs, the quality of educational resources, the quality of teachers and education managers, thequality of the learning process, the ability of education managers to anticipate, and handle various influences of the educational environment. In terms of education, Makawimbang [2] states that supervision is interpreted as coaching given to all school staff so that they can improve their ability to develop better teaching and learning situations. According to Ahmad Sofyan et al., [3] explained that 
the supervision of learning is an inseparable part of the supervision of education. Substantially, education supervision is an effort made in schools or Islamic school to improve the quality of the education process and is supported by optimizing the role of teachers, availability of facilities and infrastructure, curriculum design, learning systems and assessment and measurement mechanisms.

According to Ngalim Purwanto [4] supervision has a broad understanding, namely all assistance from school leaders aimed at the development of leadership of teachers and other school personnel to achieve educational goals. In principle, supervision is guidance and assistance to teachers. Assistance provided to teachers must be based on research or careful observation and an objective and in-depth assessment concerning the planning of the learning program that has been made. The assistance process is oriented towards efforts to improve the quality of the process and learning outcomes are important, so that the assistance provided is truly on target. So, the assistance provided by the supervisor must be able to improve and develop the teaching and learning situation. As a leader, the principal or Islamic school should improve the performance and professionalism of teachers, to realize an effective learning process. As an education leader, the principal or Islamic school plays a role in creating a learning process situation, so that teachers can teach well and students can learn well too. In carrying out this role, the principal or Islamic school has a dual responsibility of carrying out the administration of the school or Islamic school, to create a good teaching and learning situation, and carry out supervision, so that teachers can improve the quality of teaching and be able to guide their students.

In carrying out their duties as educators, teacher performance can be identified in the form of motivation, commitment, and responsibility in carrying out the learning process. To be able to play the role of leader, the principal or Islamic school must have five competencies. This is under Minister of National Education Regulation No. 13 of 2007 which stipulates that the competencies of principals include: personal competencies, managerial competencies, entrepreneurial competencies, supervisory competencies, and social competencies. More specifically, the Islamic school head competency is also explained in Regulation of the Minister of Religion of the Republic of Indonesia No. 58 of 2017 which explains that the Islamic school head must have competencies: personality, managerial competence, entrepreneurial competence, supervisory competence, and social competence. Islamic school head competencies above are the minimum criteria in the form of a set of knowledge, skills, and behaviors that must be possessed by teachers who are given the task of leading and managing formal education units that organize education in Islamic school educational institutions. In innovating and developing creativity under their duties and responsibilities as a supervisor, competence is needed. The existence of competence greatly affects the smoothness and achievement of educational goals.

In carrying out their leadership tasks, especially in efforts to improve the quality of education, the principal or Islamic school can carry out the supervision of learning to overcome the problems faced by teachers in the Islamic school. Teacher abilities, desires, and personalities are not the same between one teacher and another teacher. This difference directly affects the professionalism and performance produced by teachers in carrying out their daily tasks. The problem that is still encountered today is that the principals or Islamic schools as supervisors do not understand their tasks and functions well so that when carrying out supervisory tasks they are not optimal. Another problem is that there are still principals or Islamic school who do not carry out routine supervision tasks so that it brings a negative impact on teacher performance in carrying out learning activities, such as lack of motivation and decreased performance so that it will have an impact on the quality produced. Other obstacles commonly faced by principals or Islamic school as supervisors include: there are still many teachers who do not understand their functions and roles well as instructors and educators, such as often teachers leave assignments as instructors. Reality like this is a phenomenon that is often and commonly occurs in a school or Islamic school.

Dadang Suhardan [5] explains that supervision is interpreted as professional assistance that seeks to empower and continuously coach for teachers which includes the process of coaching teachers in their professional assignments (in-service professional development). Meanwhile, according to Glickman and Ross Gordon [6] mentioning in practice, a supervisor harmonizes assistance to the teacher with the conceptual level of the teacher, primarily aimed at understanding the teacher to be responsible for self-improvement, so that supervision can guide the teacher in the framework of learning repair or improve itself. Institutionally according to Burhanudin [7] explains that the development and improvement of competencies and teacher performance can be done through professional assistance efforts that enable teachers to grow, develop, and improve their professional abilities, and learn to improve their professional capacity, namely in the form of supervision. Supervision, as well as teacher professional guidance, is a service that is used interchangeably as seen from the 1975, 1984 and 1994 curriculum documents for elementary schools and the 1994 curriculum documents for general secondary schools. Professional coaching and supervision are not the same, but are related to one another, and so is evaluation. Professional development and teacher evaluation are different from instructional supervision 
(instructional supervision), which is one of the teacher's professional development strategies with peer-coaching, induction, group learning, and portfolio development activities.

The importance of the supervision of learning also appears in the existing phenomenon, that the ministry of religion continues to strive for the realization of quality educational services, especially in the scope of Islamic schools, including the implementation of learning supervision conducted by the headmaster, deputy headmaster, and senior teachers. Implementation of learning supervision is expected to be able to: (1). improve the quality and professionalism of teachers in the learning process, so that with a good learning process, will improve the quality of education; (2) empowering the learning supervision implementation team in Islamic school which includes: Islamic school head, Islamic school deputy head, and senior teachers; (3) develop teacher professionalism by focusing on professional competencies and pedagogical competencies; (4) activate the functions and responsibilities as well as the authority of the Islamic school head as the supervisor in the Islamic school institution. So, overall, supervision is the main task and responsibility of the Islamic school head.

Thus, supervision is very important in ensuring educational institutions perform professional services. The educational supervision process is no longer only administrative in nature but is mandatory (mandate) for supervisors (principals or Islamic school) to meet the needs of users who need multidisciplinary educational services, both academic administrative and moral. In the theory of administrative science, principals or Islamic school must master administrative problems both in primary, secondary and high school. William G. Monahan [8] reveals that if there is one thing that can be said with some understanding about the administrators of modern education, whether in elementary school, middle school or in high school. In line with this, Ahmad Bin Daud Al-Mizjaji al-Ash'ari [9] explains what it means: Administration must be done by carrying out something; with the achievement of specified goals.

In the management process, according to Binti Maunah [10] supervision is under "controlling" of the supervision. Therefore, supervision in an educational organization is needed as a dynamic tool and can be a basic tool for all components of education in carrying out the duties and responsibilities of educational actors under the plans and objectives set. Once the role of supervisors is important, the quality and existence must be taken into account, although in some facts the implementation of supervision by the principal or Islamic school is maximized. This kind of understanding is not true for the present, because the principal or Islamic school is the top leader and activator and determinant of how educational institutions in Islamic schools are more qualified. The quality of a school or Islamic school is determined by how the principal or Islamic school in formulating the vision, mission, and objectives to be achieved. Thomas J. Sergovanni, Martin Burlingame, Fred S. Combs, Paul W. Thurston [11] state leadership activities associated with the cultural view include articulating school purposes and mission. This means that the principal's / Islamic school's leadership activities are closely related to the process of articulating the goals and missions of the school.

In carrying out his profession as a supervisor, the Islamic school head must meet the competencies and other requirements under existing rules. Besides, the Islamic school head must have creative and innovative abilities to be able to carry out their duties more optimally. As a think tank, supervisors are required to have strong thinking power, so that they can carry out their duties and obligations well. To ensure that this kind of research is feasible and can contribute to science, researchers consider and conduct several studies of results related to supervision research in the last decade by studying several research journals about supervision.

The study in the research above shows that supervision of learning is very important and useful to help teachers develop professionally and improve the quality of learning so that it has a positive effect on student achievement. The results of these studies indicate that there are still problems with supervision that require further study, namely: (1) lack of teacher involvement in all supervision processes, (2) lack of principal or Islamic schoolh skills as supervisors and lack of expertise in supervised subjects, (3) teachers' trust in supervisors and administrator's attitude is less positive towards supervision activities, (4) supervision as development is not done, (5) there is still hope that supervision will help if done correctly, and (6) the supervision activities have not been maximized by Islamic school head at an advanced intermediate level. Assistance provided to teachers is useful in guiding themselves and lifelong learning in line with the development of knowledge that is still needed. Throughout the experience of researchers, while working in the office of the ministry of religion as supervisors of Islamic religious education, as well as supervisors of Islamic schools, researchers found elements of teacher involvement and the skills of Islamic school principals as supervisors largely determine the success and effectiveness of supervision.

Based on the facts above, it is clear that the role of the principal or Islamic school is very dominant in improving the quality of education through supervision activities, especially in terms of supervision of learning. This research is conducted because based on the observations of researchers, the two institutions are very good quality and always performed well in 
every activity at the district, provincial and national levels both in academic and non-academic fields. This can be seen from the increasing development of the number of students that occur each year. In terms of a good learning process, the development of students is quite rapid, so researchers want to find out more and deeper in terms of learning activities and processes, especially in the supervision of learning activities carried out by the headmaster. Researchers are guided by the progress of an educational institution in the quality of education. Besides, the quality of education is inseparable from the learning process in Islamic schools and good learning processes and is inseparable from the implementation of supervision conducted by the Islamic school headmaster.

\section{METHOD}

The approach that researchers do is under the concept of qualitative research. According to Amad Tanzeh [12] that is research intended to uncover holistic-contextual phenomena through collecting data from natural settings as a direct source with the researchers' key instruments themselves. In other words, according to Bogdan and Biklen [13] this research is descriptive, meaningful, and not focused on the quantity of data, so the appropriate research is a qualitative approach. This study aims to get an in-depth overview of the supervision of learning conducted by the headmaster in both institutions, including aspects of learning supervision planning, implementation of learning supervision and evaluation of learning supervision in improving the quality of learning.

In this study, the conditions of the two Islamic schools that are far apart have different characteristics but have similar cases. Phenomenon tracking focuses on the supervision activities of learning at MAN 1 Trenggalek and MAN 2 Trenggalek, which supervised learning involving the headmaster, deputy headmaster, and senior teachers. This type of research is field research using a multi-site design, and the subjects studied are in MAN 1 Trenggalek and MAN 2 Trenggalek. Although the two Islamic Senior High Schools have different characteristics, however both apply similar learning supervision.

\section{RESULTS AND DISCUSSION Planning Academic Supervision}

Academic supervision planning is to determine some activities that will be carried out in the implementation of learning supervision. Planning is a very important thing in achieving a goal. The purpose of this supervision is held as an effort to encourage teachers to develop their competencies, so they can achieve better goals. Academic supervision planning must be made as a guideline in carrying out tasks so that educational goals are achieved as expected. Planning is the process towards achieving certain goals or in other terms is a directed and systematic preparation so that goals can be achieved effectively and efficiently.
According to George R Terry [14] planning is a process of selecting and linking facts by using assumptions about the future in making visualizations and formulating proposed activities. This is indeed necessary to get the desired results. While Louis A Allen [15] states that planning consists of activities arranged by a manager in thinking ahead and making decisions. The planning activities referred to here are forecasting, establishing objectives and programming. A plan is an integrative activity that seeks to maximize the overall effectiveness of an organization as a system, and under the objectives to be achieved. Based on this definition, planning must have at least the following three characteristics, namely the future, personal actions and identification, and organization.

Academic planning is a very important process in the implementation of academic supervision to achieve goals. All management functions without planning, so the other functions such as organizing, directing, and controlling, will not run properly. Ahmad Sofyan [3] mentioned that planning is a process in selecting and linking facts by using several assumptions about the future in making visualization and formulation of proposed activities. This is indeed necessary to get the desired results. The needs are availability of facilities and infrastructure, curriculum design, learning systems and assessment, and measurement mechanisms.

In academic supervision planning, making a supervision program for the headmaster is the right step to formulate a strategy in supervision activities. The supervision program for the heads of MAN 1 and MAN 2 Trenggalek aims: (1) as a reference for the implementation of supervision activities within the MAN Trenggalek environment; (2) increasing the professionalism of teachers in carrying out their main tasks and functions as educators; (3) improving the quality of the learning process in each subject that leads to improving the quality of graduates; (4) In addition, in addition to academic supervision, this supervision program is also complemented by managerial supervision in each activity unit in MAN 2 Trenggalek which is an internal supervision in order to improve the quality of management of school and Islamic school administration and activity units.

Technically, the next step taken by the Islamic school head in planning supervision of learning is to prepare several instruments to be used in carrying out supervision. The learning supervision plan compiled by the Head of MAN 1 and MAN 2 Trenggalek includes work programs, supervision programs in which there are several instruments as measuring instruments. From the above explanation, it is clear, that the Head of MAN 1 and MAN 2 Trenggalek conducts supervision planning by compiling learning supervision instruments in the framework of the standard size of the results obtained by the teacher. 


\section{Implementation of Academic Supervision}

Islamic school principals carry out supervision activities under the plans that have been outlined in the Islamic school head supervision program. This is in the form of a learning supervision document. The supervision of learning in MAN 1 and MAN 2 Trenggalek is done not only by the headmaster of Islamic school but also by the supervisor of the Islamic school. This is done twice each semester. In carrying out its role as a supervisor, the Islamic school head must know and understand and master some of the principles and techniques of supervision. This serves to make the implementation run according to the purpose of supervision. In the Regulation of the Minister of Religion of the Republic of Indonesia Number 58 the Year 2017 it is explained, that the Islamic school head carries out managerial tasks, develops entrepreneurship and supervises teachers and education staff. While the competencies that must be possessed by the Islamic school head based on the Minister of National Education Regulation No. 13 of 2007 concerning Principal Standards are Islamic schools consisting of 5 competencies including managerial competence, entrepreneurial competence, supervision competency, personality competence, and social competence. Ara Hidayat and Imam Machali [1] explain the supervision of learning has an important role in efforts to improve the competence and professional abilities of teachers. The following is a chart of the relationship between educational supervision, teaching behavior, learning behavior, and learning outcomes.

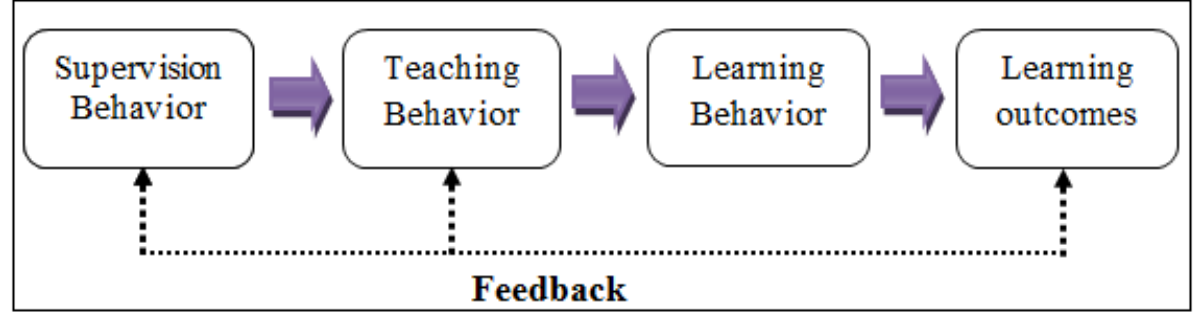

Fig-1

It tends to the relationship among supervision behavior, teaching behavior, learning behavior, and learning outcomes.

Academic supervision according to Ngalim Purwanto [4] can be carried out in various ways, with the aim that what is expected together can become a reality. Broadly speaking, the method or technique of supervision can be classified into two, namely individual techniques and group techniques. The several supervisory principles according to Daryanto and Tutik Rachmawati [16] include scientific, democratic, cooperative, constructive and creative principles. In the supervision activities of Islamic school principals in MAN 1 and MAN 2 Trenggalek uses several supervision principles and approaches as described above. Whereas the approaches and methods used are varied techniques and approaches, and are carried out in a pleasant atmosphere. This is as explained in the principles of supervision, namely the democratic principle can be interpreted that the assistance provided to teachers is based on close humanitarian relations, so that teachers feel safe to develop their duties. Meanwhile, at MAN 2 Trenggalek, the Islamic school head uses the principles and supervision approach, namely by conducting intensive guidance to teachers, individual approaches and problem-solving methods, as well as innovating in the process of supervision of learning.

In more detail, some formulations about some of the steps in implementing supervision of learning conducted by Islamic school principals in both MAN 1
Trenggalek and MAN 2 Trenggalek are (1) notification and preparation of supervision schedules; (2) direct checking of learning tools; (3) supervising class visits, (4) evaluating and following up on supervision; (5) compiling curriculum in accordance with community needs; (6) innovating approaches and supervision methods; (7) providing free internet services to teachers; and (8) continuing mentoring and mentoring for teachers.

To conduct guidance, the Koran, in this case, has provided a basic foundation for the process of guidance and direction or provides warnings in the form of actuating. The description is under the word of Allah SWT which means: As straightforward guidance, to warn of extremely painful torment from Allah's side and give glad tidings to those who believe, who do righteous deeds, that they will get good retribution (Surah AlKahf 18: 2).

The above paragraph explains that the steps for implementing the supervision of learning are carried out by the Islamic school head by way of guidance and assistance to the teacher. This is done, both at MAN 1 and MAN 2 Trenggalek. This method is very effective because, with the assistance of the Islamic school head to the teacher, there will be a good inner connection, all kinds of problems in the learning process can be resolved properly. This is a factor in achieving the learning supervision implementation plan is by guiding and giving warnings. If this is ignored, it will be an adverse effect on the survival of an organization and institution. The supervision of school principals or 
Islamic school is inseparable from the approach and supervision techniques that were discussed in the initial explanation. To achieve the stated goals of supervision, a supervisor can use a variety of techniques. Piet A. Sah understanding classifies supervision techniques into two types, namely individual techniques and group techniques. Individual techniques include; class visits, class observations, personal conversations, intervention, and self-assessment. Group techniques include; (1) orientation meetings with teachers; (2) organizing committee; (3) teacher meetings; (4) group studies; (5) discussion; (6) experience exchange; (7); workshop; (8) symposium; (9) teaching demonstrations; (10) position library; and (11) school trips for staff members.

The implementation of academic supervision also uses individual techniques and group techniques. This can be seen with the supervision activities that have been carried out by the Islamic school head as done, both in MAN 1 and MAN 2 Trenggalek. Thus, supervision techniques are very important to be mastered by the principal. Without the mastery of this technique, the implementation of supervision will not run well. Supervision techniques will make it easier to achieve some of the goals set. Therefore, the application of techniques from supervision is a form of school progress to develop. In practice, supervision of learning will improve the learning process, if done using several applicable principles and approaches. Therefore, as a supervisor, the principal must know in advance its role and function as a person who can help and provide assistance to teachers in improving the learning process in the Islamic school. The process of implementing a learning supervision program can be done consequently. So the implementation of this program can certainly improve the learning process carried out by teachers at this time, especially teachers in MAN 1 and MAN 2 Trenggalek. The goal is that from less effective will become more effective from less meaningful will become more meaningful.

\section{Evaluation of Academic Supervision}

Evaluation of academic supervision is done by reflecting on the learning that has been carried out. This reflection is carried out by the teacher together with the supervisor or the Islamic school head. The results of the reflection phase are recorded and will be used as material for a follow-up. But in practice, it is often not implemented. From several notes, what was found, was not followed by discussion and was only a note without any follow-up. Evaluation of learning supervision programs is the provision of estimates of the implementation of learning supervision to determine the effectiveness and progress to achieve the stated learning supervision goals. In evaluating learning supervision programs, teaching improvement involves elements in determining the changes that occur in certain periods. Expected changes from all personnel in supervision, and program improvements that involve the principal (supervisor), teacher, and students. Supervisors and teachers work together to bring some changes in students. Besides, several things that must be considered as an evaluation effort are the problem of the scope of learning supervision which includes improvement plans, organizational planning, objectives to be achieved, some techniques for achieving supervision objectives, and some changes made in the curriculum and guidance areas.

Evaluation of academic supervision programs does not mean evaluating a learning design by trying to determine to what extent the educational supervision goals have been achieved. Therefore, not only the program is evaluated, but also the process of implementation and the results of the supervision of education. The scope of the evaluation of educational supervision concerns all the components involved in the implementation of educational supervision. These components include aspects of personnel, material aspects, and operational aspects in the supervision of learning. Every activity carried out by humans certainly has a certain goal, because activities with having noa purpose defines as an activity or work in vain. Likewise, the supervision of learning conducted by the Islamic school head must have the objectives as described above. This is under the word of Allah, which means: Whereas they are not told, except to worship God by purifying obedience to Him in (practicing) righteous religion, so that they establish prayers and perform alms; and that is the true religion (Surah $\mathrm{Al}$ Bayyinah 98: 5) [17].

Based on the research, it was found that the coaching evaluation activities conducted by the Islamic school head were based on several notes on the format of the class visit and the implementation of observations to the teachers. It is intended as material to conduct analysis and input in making a coaching program for teachers for the next step. The Islamic school head evaluates each activity and prepares a Follow-up Plan. The follow-up activities of the Islamic school head were given the opportunity for the teacher to actively participate in $M G M P$ activities as explained above in the implementation of learning supervision.

In conducting evaluations, the Islamic school head as an evaluator in the initial stages must determine the focus to be evaluated and the design to be used. Furthermore, Brikerhoff in Mardapi [18] argues that the implementation of the evaluation of the seven elements that must be done, namely (1) focusing the evaluation; (2) designing evaluation; (3) collecting information; (4) analyzing and interpreting the information; (5) reporting information; (6) managing evaluation; and (7) evaluating evaluation.

In order to carry out evaluation and follow-up regarding the implementation of learning supervision, a number of things are carried out, namely (1) compiling the success criteria of learning supervision; (2) 
formulating criteria for the effectiveness of the learning supervision implementation process; (3) formulating the criteria for achieving the learning supervision goals; (4) formulating the criteria for achieving the effects of learning supervision; (5) developing learning supervision instruments; (6) developing data collection instruments in order to identify and analyze problems or learning development needs; (7) developing instruments for measuring the effectiveness of the implementation of learning supervision in accordance with the area being worked on, the approach and supervision techniques applied; (8) developing instruments for measuring the achievement of direct results (outputs) of learning supervision according to the area being worked on; and (9) developing instruments for measuring the impact of learning supervision in accordance with the area being worked on.

In MAN 1 and MAN 2 Trenggalek, the Islamic school head conducts evaluation activities based on several notes on the format of class visits to teachers for each year. This is intended to be used as material for analysis and input in making training programs for teachers in the following year and is useful for the implementation of follow-up. At the follow-up stage, observations are openly discussed between the Islamic school headmaster and the teacher. Another thing in the discussion on the evaluation of learning supervision is the headmaster of Islamic school compiling reports on the results of supervision, analyzing, processing data and solving problems. More carefully, it is in the interest of the learning process carried out in class. One performance of Islamic school principals that must not be ignored and is an obligation of every Islamic school head is to provide a written report to his superiors, namely supervisor supervisors and the office of the Ministry of Religion of Trenggalek Regency. The submission of reports is control by the supervisor's unit to the employee who has carried out the task periodically. Giving a report is authentic evidence that is transparent to all tasks that have been carried out. Activity reports are made monthly and need to be made so that the work program can be controlled as well as the responsibility of each supervisor in carrying out their duties. With the accountability report on the implementation of the program, it can be seen the implications of the performance of the Islamic school head, whether it is useful for teachers, Islamic school, teachers and Islamic school management, and the achievement of educational goals. From the results of the data mentioned that the implementation of learning supervision can improve the performance of teachers MAN 1 and MAN 2 Trenggalek.

Based on the explanation above, it can be concluded that the supervision activities carried out by the Islamic school head to the teacher in the learning process are his duties and responsibilities in organizing education in schools. Therefore, supervision activities must be carried out appropriately and effectively so that the implementation of effective supervision will be able to help teachers in the process of learning activities in an Islamic school.

\section{CONCLUSION}

Efforts to improve the quality of learning can be done through referring to the main tasks and competencies of Islamic school principals, namely carrying out academic supervision. The first step taken by the Islamic school head is to plan academic supervision in the form of design contained in the work program and the Islamic head supervision program. The headmaster of the Islamic school has an easy task to condition the teachers in preparing the learning process. The position of the Islamic school head in terms of supervision is crucial in improving the quality of learning in the classroom and improving learning is closely related to the quality of performance and professionalism of teachers.

In the case of implementation, the Islamic school head must carry out supervision at least once in a semester. This is happened due to the task of the Islamic school head is currently focused on managing or controlling the institution he leads. The process that must be gone through by the headmaster of Islamic school is to start from the supervision planning and supervision evaluation. Based on the workflow of the headmaster, it is expected that the implementation of academic quality can be achieved well. Academic supervision activities are focused on teachers in learning so that the quality of students becomes better. The direct impact of the process, the teacher can increase his competence, especially his professional competence.

\section{REFERENCES}

1. Ara Hidayat dan Imam Machali. (2012). Pengelolaan Pendidikan. Yogyakarta:

KAUKABA.

2. Makawimbang. (2011). Supervisi dan Peningkatan Mutu Pendidikan. Bandung: Alfabeta,

3. Ahmad, S. (2005). Peningkatan Supervisi dan Evaluasi Pada Islamic school ibtidaiyah. Jakarta: Departemen Agama RI, Dirjen Kelembagaan Agama Islam.

4. Ngalim, P. (2014). Administrasi dan Supervisi Pendidikan. Bandung: PT. Remaja Rosdakarya.

5. Dadang, S. (2010). Supervisi Profesional: Layanan dalam Meningkatkan Mutu Pembelajaran di Era Otonomi Daerah. Bandung: Alfabeta.

6. Glickman dan Ross Gordon. (1987). Clarifying Development Supervision. Alexandria, VA: ASCD.

7. Burhanudin. (2007). Supervisi Dalam Rangka Pembinaan Profesional. Malang: FIP UNM.

8. William, G. M. (1974). Theoretical Dimensions of Educational Administration. New York: Macmillan Publishing CO.INC. 
9. Ahmad Bin Daud Al-Mizjaji al-Ash'ari. (2000). Muqadimat fii Idaaarat al-Islamiyat, Jeddah: alMamlakat al-Árabiyat as-Saudiyat.

10. Binti, M. (2009). Supervisi Pendidikan Islam,Teori dan Praktik. Yogyakarta: TERAS, cetakan ke-1.

11. Thomas, J. S., Martin, B., Fred, S. C., \& Paul, W. T. (1987). Educational Governance and Administration. University Of Illinois: Urbana Champaign.

12. Ahmad, T. (2011). Metodologi Penelitian Praktis. Yogyakarta: Teras.

13. Bogdan dan Biklen. (1982). Qualitative Research for Education: An Introduction to Theory and Methods, London: Allyn and Bacon, In.
14. George, R., \& Terry, G. R. (2003). Prinsip-prinsip Manajemen. Bandung: Bumi Aksara.

15. Louis, A. A. (2005). Perencanaan merupakan Aktifitas Prakiraan, Penetapan Tujuan dan Pemrogaman". Lihat Siswanto, Pengantar Manajemen. Bandung: Bumi Aksara.

16. Daryanto dan Tutik Rachmawati. (2015). Supervisi Pembelajaran Inspeksi meliputi: Controlling, Correcting, Judging, Directing, Demonstration, Yogyakarta: Gava Media.

17. QS. Al Bayyinah (98): 5.

18. Mardapi, D. (2000). Evaluasi Pendidikan. Jakarta: UNJ. 